\title{
Blood gases of horses subjected to jugular vein occlusion during treadmill exercise
}

\section{Gases sanguíneos em equinos submetidos à oclusão da veia jugular durante o exercício em esteira}

\author{
Deborah Penteado Martins Dias ${ }^{1 *}$; Marco Augusto Giannoccaro da Silva ${ }^{2}$; \\ Raquel Mincarelli Albernaz ${ }^{3}$; Lina Maria Wehrle Gomide ${ }^{1}$; Carla Braga Martins ${ }^{4}$; \\ Nara Saraiva Bernardi'; José Carlos Barbosa ${ }^{1}$; Antonio de Queiroz-Neto ${ }^{1}$; \\ José Corrêa de Lacerda-Neto ${ }^{1}$
}

\begin{abstract}
The purpose of the present investigation was to examine the effects of unilateral and bilateral jugular vein occlusion via temporary surgical ligature on arterial blood gases in horses during treadmill exercise. Six horses performed three exercise tests (ETs). ET1, considered to be the control, was performed in horses without jugular occlusion. ET2 and ET3 were performed in horses with unilateral and bilateral occlusion via temporary surgical ligature of the jugular veins, respectively. The partial pressure of oxygen $\left(\mathrm{PO}_{2}\right)$ and partial pressure of carbon dioxide $\left(\mathrm{PCO}_{2}\right)$ were determined. The $\mathrm{PO}_{2}$ showed decreased values during ET2 and ET3, suggesting that horses presenting acute jugular thrombophlebitis may have airflow limitations when exercising.
\end{abstract}

Key words: Blood gases, equine, swan ganz, thrombophlebitis, upper airways

\section{Resumo}

O objetivo do presente trabalho foi avaliar os efeitos da oclusão da veia jugular por ligadura cirúrgica unilateral e bilateral sobre os gases do sangue arterial em equinos durante o exercício em esteira. Seis equinos realizaram três exercícios teste (ETs). ET1, considerado como controle, foi realizado por equinos sem oclusão jugular. ET2 e ET3 foram cumpridos por equinos apresentando oclusão da veia jugular por ligadura temporária unilateral e bilateral, respectivamente. A pressão parcial de oxigênio $\left(\mathrm{PO}_{2}\right)$ e a pressão parcial de dióxido de carbono $\left(\mathrm{PCO}_{2}\right)$ foram determinadas. $\mathrm{A}\left(\mathrm{PO}_{2}\right)$ demonstrou diminuição em ET2 e ET3, sugerindo que equinos com tromboflebite jugular aguda podem apresentar limitação no fluxo de ar inspirado durante o exercício.

Palavras-chave: Equino, gases sanguíneos, swan ganz, tromboflebite, vias aéreas superiores

\footnotetext{
${ }^{1}$ Profs., Faculdade de Ciências Agrárias e Veterinárias, FCAV, Jaboticabal, SP, Brasil. E-mail: deborah_dias@hotmail.com; linagomide@gmail.com; jcbarbosa@fcav.unesp.br; aqueiroz@fcav.unesp.br; jlacerda@fcav.unesp.br

2 Prof., Universidade Federal do Tocantins, UFT, Araguaína, TO, Brasil. E-mail: silva_vet@hotmail.com

3 Pesquisadora, Ouro Fino Saúde Animal, Cravinhos, SP, Brasil. E-mail: raquel.albernaz@ourofino.com

${ }^{4}$ Prof ${ }^{a}$, Universidade Federal do Espírito Santo, UFES, Alegre, ES, Brasil. E-mail: cbmvt@hotmail.com

5 Discente, Faculdade de Ciências Agrárias e Veterinárias, FCAV, Jaboticabal, SP, Brasil. E-mail: nara.sb@gmail.com

* Author for correspondence
} 
As a result of their evolution as grazing animals running on the ancient prairies of Asia, horses are athletes by nature, and their superior ability to perform physical activities is attributable to their high aerobic capacity (HINCHCLIFF; GEOR, 2004). Therefore, considering that aerobic metabolism is the predominant energy pathway for most sports, any disease that impairs ventilation could decrease performance (VAN ERCK-WESTERGREN et al., 2013). Disorders involving the upper respiratory tract, such as dorsal displacement of the soft palate, axial deviation of the aryepiglottic folds and idiopathic laryngeal hemiplegia, have been identified as important causes of poor performance in athletic horses. These diseases limit ventilation through dynamic obstruction of the upper airways (MARTIN et al., 2000; TAN et al., 2005).

Jugular thrombophlebitis in horses can also be a cause of upper airway narrowing. Impairment of blood flow due to reduction of the vascular lumen via partial or complete occlusive thrombus could lead to head venous congestion and the development of upper airway edema and consequent dyspnea, especially when both jugular veins are involved (EDENS, 1999; BONAGURA, 2010). This condition may evolve to recanalization of the vein when blood flow is restored, or the thrombus may become fibrous, resulting in permanent occlusion, either followed by the development of collateral circulation or not (LANKVELD et al., 2001; MOREAU; LAVOIE, 2009; RUSSELL et al., 2010; HUSSNI et al., 2012; DIAS et al., 2014). If the horse resumes its physical activities while presenting a jugular thrombotic occlusion, and collateral vascularization does not occur, its performance is suspected to be limited (MOREAU; LAVOIE, 2009; DIAS et al., 2013). The objective of the present study was to examine the effects of unilateral and bilateral jugular vein occlusion via temporary surgical ligature on the arterial blood gases of sedentary horses during progressive exercise on a treadmill, with the aim of understanding these effects in athletic horses presenting jugular thrombophlebitis.
All experimental protocols performed in the current study were approved and supervised by the institutional committee on animal research and ethics (Protocol \#004302-06). Blood gas analysis was performed as a complement to an experimental protocol for studying hemodynamics in horses during treadmill exercise (DIAS et al., 2013). Thus, some procedures were similar, including the surgical technique to occlude jugular veins. Six adult mixed breed sedentary horses, including 3 males and 3 females, with a mean age of $6 \pm 1$ years and a mean body weight of $344 \pm 12 \mathrm{~kg}$ were used. All of the horses were considered healthy based on a physical examination and blood count (PocH-100iV Diff, Sysmex, Brazil).

The 6 horses performed 3 sessions of an incremental exercise test (ET) on a high-speed treadmill (Galloper, Sahinco, Palmital, Brazil). One week before the tests, the horses were accustomed to the treadmill for 3 days, so that they could walk, trot and canter without difficulty. The first test (ET1), considered to be the control, was performed in horses without jugular vein occlusion. The second (ET2) and third (ET3) tests were performed in horses with occlusion via ligature of the left jugular vein and with occlusion via ligature of both jugular veins, respectively. There was 24-hour interval between tests. The total duration of each test session was 83 minutes, and the tests were rigorously timed according to a predetermined rest and exercise sequence (Table 1).

Arterial blood samples were collected during the 3 tests at 13 time points (T0-T12) per test. For this purpose, a $20 \mathrm{~cm}$ polyurethane catheter (Central Venous Catheterization Set, REF CV-04701, Arrow International, Reading, USA) was implanted into the left facial artery and flushed every 8 hours with a $10 \%$ ascorbic acid solution containing $5,000 \mathrm{U} \mathrm{mL}^{-1}$ of sodium heparin (DIAS et al., 2012) until the end of ET3, when it was removed. During the exercise test, the catheter remained filled with heparinized saline solution (10 UI mL $\mathrm{mL}^{-1}$ ), which was withdrawn and discarded before each collection. Samples were 
obtained anaerobically in $1 \mathrm{~mL}$ heparinized syringes and immediately analyzed in a blood gas counter (OMNI-C, Roche, São Paulo, Brazil). The partial pressure of oxygen $\left(\mathrm{PO}_{2}\right)$, partial pressure of carbon dioxide $\left(\mathrm{PCO}_{2}\right), \mathrm{pH},\left[\mathrm{HCO}_{3}^{-}\right]$and base excess (BE) were determined. To correct the obtained $\mathrm{PO}_{2}, \mathrm{PCO}_{2}$ and $\mathrm{pH}$ values, body temperature was measured continuously during exercise using a 5
French Swan Ganz (132F5, Edwards Lifesciences, Irvine, USA) introduced through a conventional $14 \mathrm{G}$ catheter (BD Insyte ${ }^{\mathrm{TM}}$ 14GAx1.75IN, Becton Dickinson, Juiz de Fora, Brazil) implanted into the right jugular vein, caudal to the ligature. The Swan Ganz was fixed to the skin with one simple suture and connected to a multiparametric monitor (DX2010, Dixtal, São Paulo, Brazil).

Table 1. Treadmill exercise test protocol performed by horses subjected to treadmill exercise tests (ET) without jugular vein occlusion (ET1), with unilateral jugular vein occlusion (ET2) and with bilateral jugular vein occlusion (ET3).

\begin{tabular}{|c|c|c|c|c|c|}
\hline \multirow{2}{*}{$\begin{array}{c}\text { Condition } \\
\text { REST }\end{array}$} & \multirow{2}{*}{$\begin{array}{c}\text { Duration } \\
5^{\prime}\end{array}$} & \multirow{2}{*}{$\begin{array}{c}\text { Speed } \\
0 \mathrm{~m} / \mathrm{s}\end{array}$} & \multicolumn{2}{|c|}{ Measurements at } & \multirow{2}{*}{$\frac{\text { Cumulative time }}{5}$} \\
\hline & & & T0 & $4^{\prime}$ & \\
\hline \multirow{2}{*}{ WARM-UP } & $10^{\prime}$ & $1.7 \mathrm{~m} / \mathrm{s}$ & $\mathrm{T} 1$ & $14^{\prime} 30^{\prime \prime}$ & $15^{\prime}$ \\
\hline & 5 & $3.5 \mathrm{~m} / \mathrm{s}$ & $\mathrm{T} 2$ & 19’30" & $20^{\prime}$ \\
\hline \multirow{6}{*}{$\begin{array}{l}\text { PROGRESSIVE } \\
\text { EXERCISE }\end{array}$} & $3^{\prime}$ & $4.5 \mathrm{~m} / \mathrm{s}$ & T3 & $22 ’ 30^{\prime \prime}$ & $23^{\prime}$ \\
\hline & $3^{\prime}$ & $5.5 \mathrm{~m} / \mathrm{s}$ & $\mathrm{T} 4$ & $25^{\prime} 30^{\prime \prime}$ & $26^{\prime}$ \\
\hline & $3^{\prime}$ & $6.5 \mathrm{~m} / \mathrm{s}$ & T5 & $28^{\prime} 30^{\prime \prime}$ & $29^{\prime}$ \\
\hline & $3^{\prime}$ & $7.5 \mathrm{~m} / \mathrm{s}$ & T6 & $31 ’ 30^{\prime \prime}$ & $32^{\prime}$ \\
\hline & $3{ }^{\prime}$ & $8.5 \mathrm{~m} / \mathrm{s}$ & $\mathrm{T} 7$ & $34^{\prime} 30^{\prime \prime}$ & 35, \\
\hline & 3 & $9.5 \mathrm{~m} / \mathrm{s}$ & $\mathrm{T} 8$ & $37 ’ 30^{\prime \prime}$ & 38 \\
\hline \multirow{2}{*}{ COOL DOWN } & 5 & $3.5 \mathrm{~m} / \mathrm{s}$ & T9 & $42 ’ 30 ”$ & $43^{\prime}$ \\
\hline & $10^{\prime}$ & $1.7 \mathrm{~m} / \mathrm{s}$ & $\mathrm{T} 10$ & $52^{\prime} 30^{\prime \prime}$ & $53^{\prime}$ \\
\hline \multirow{2}{*}{ REST } & \multirow{2}{*}{30} & \multirow{2}{*}{$0 \mathrm{~m} / \mathrm{s}$} & $\mathrm{T} 11$ & 68 & 68 \\
\hline & & & $\mathrm{T} 12$ & $83^{\prime}$ & $83^{\prime}$ \\
\hline
\end{tabular}

The obtained values were analyzed by ANOVA, and the means were compared via Tukey's test using software (AgroStat, version 1.1.0.626/2011, Jaboticabal, Brazil). A significant difference between means was considered at $\mathrm{P}<0.05$. The data are shown as the means \pm standard error of the mean (SEM).

To investigate the effects of jugular vein occlusion on blood gases during physical activity, horses were subjected to treadmill exercise tests. Treadmill protocols are widely used to evaluate conditioning, and variables such as $\mathrm{pH}, \mathrm{PO}_{2}$ and $\mathrm{PCO}_{2}$ are useful for determining the acid-base balance (LINDINGER; HEIGENHAUSER, 2008). However, body temperature must be measured to obtain these values, and the usual mode of measurement via the rectal route may compromise the results obtained for blood gases during an ergometric test, as the treadmill must be stopped to collect data. In this particular context, a 5 French Swan Ganz catheter was implanted through a 14 $\mathrm{G}$ catheter into the jugular vein, which has been demonstrated to be a useful and minimally invasive tool for measuring body temperature continuously during exercise.

There was no difference in the values of $\mathrm{PO}_{2}$ and $\mathrm{PCO}_{2}$ among time points during ET1. However, $\mathrm{PO}_{2}$ and $\mathrm{PCO}_{2}$ showed variations within the tests performed with jugular vein occlusion (ET2 and ET3). The $\mathrm{PO}_{2}$ showed decreased values during 
the warm-up walk (T1) and during the progressive exercise phase (T3-T9) compared with the value obtained at rest 30 minutes after the end of the exercise period (T12). The $\mathrm{PO}_{2}$ and $\mathrm{PCO}_{2}$ data are displayed in table 2. Regardless the disorder involving the upper airway, a reduced level of ventilation can be detected objectively by the determination of arterial blood gas tensions (VAN ERCK-WESTERGREN et al., 2013). The decreased arterial $\mathrm{PO}_{2}$ detected during ET2 and ET3 could be related to ventilation impairment due to upper airway edema following venous congestion, as reported for clinical cases of occlusive thrombophlebitis (EDENS, 1999; BONAGURA, 2010). Clinically, unilateral occlusion via ligature leads to the development of edema, located ventral to the jaw and at the left parotid region, which was observed to be mild in 3 horses and severe in the other 3 horses. Bilateral occlusion leads to generalized head edema, especially located ventral to the jaw and in the left and right masseter muscles, parotid regions, lips and tongue. Therefore, the upper airway was also compromised, corroborating $\mathrm{PO}_{2}$ results.

Besides blood gases, values of $\mathrm{pH},\left[\mathrm{HCO}_{3}^{-}\right]$ and $\mathrm{BE}$ were also determined to evaluate acidbase balance (table 2). Reduced levels of $\mathrm{pH}$ were identified during each ET, with the lowest average values obtained at the time points of increased treadmill speed and effort intensity. During the moderate and high-intensity exercise, the energy requested by skeletal muscles exceeds their ability to produce ATP by the aerobic pathway. Thus, the energy necessary for performance is generated by anaerobic glycolysis producing lactate ( $\mathrm{La}^{-}$ ) and hydrogen protons $\left(\mathrm{H}^{+}\right)$, which reach blood circulation leading to acid-base imbalance marked by a decrease of $\mathrm{pH}$ (LINDINGER, 2004). Following the reduction of $\mathrm{pH}$, values of $\left[\mathrm{HCO}_{3}^{-}\right]$and $\mathrm{BE}$ also decreased, and this bicarbonate consumption may be associated with acidosis buffering mechanisms (CARLSON, 1995). While some authors indicated the increased concentration of $\mathrm{H}^{+}$as the main reason for $\mathrm{pH}$ decrease during maximal exercise (BÖNING;
MAASSEN, 2008), other researchers considered that $\mathrm{pH}$ reduction may also be related to the increased $\mathrm{PCO}_{2}$ (LINDINGER; HEIGENHAUSER, 2008), highlighting the importance to appreciate these variables together. However, only arterial blood samples were taken because the purpose was to evaluate ventilation indicated by $\mathrm{PO}_{2}$ levels, and it is known that arterial blood is not the gold standard to detect changes in $\mathrm{PCO}_{2}$. Furthermore, analysis of blood from a single site may not indicate the acidbase status of the body as a whole (LINDINGER; HEIGENHAUSER, 2008). No differences in acidbase balance were detected among the tests.

The effects of jugular occlusion on blood gases were not particularly strong, as there were no differences detected at the same time point when the tests were compared. Upper airway diseases are known to impair the performance of racehorses more markedly than those of horses exercising at less strenuous levels, such as dressage horses or showjumpers (VAN ERCK-WESTERGREN et al., 2013). Considering this fact, the absence of differences among tests could be attributed to the submaximal exercise level applied in this study. Moreau and Lavoie (2009) investigated the impact of chronic jugular thrombophlebitis in horses during their athletic lifespan, concluding that this disease did not affect the performance of horses used for leisure riding and other nonracing activities. However, thrombophlebitis in racing Standardbreds was found to be associated with a decreased chance of returning to racing. In addition to other causes, the authors attributed the decrease in athletic performance to edema of the nasal, pharyngeal, and laryngeal mucosa, causing airflow limitations. The present study evaluated horses subjected to jugular occlusion that performed exercise a few hours after blood flow blockage similar to an acute lesion. Collateral circulation did not develop. Thus, our results suggest that sport horses presenting acute jugular thrombophlebitis may display an impairment of ventilation during exercise. 


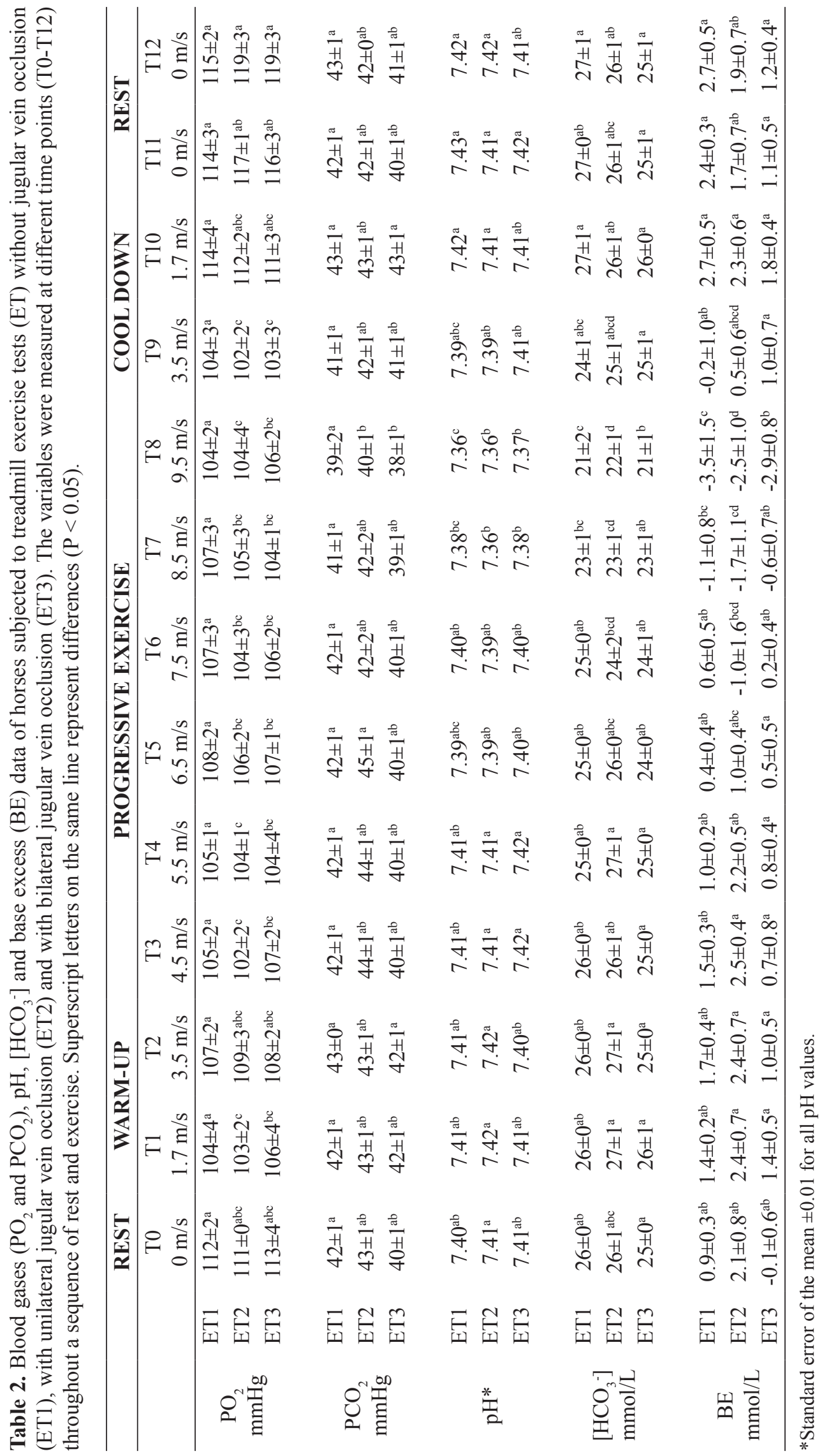




\section{Acknowledgments}

The authors acknowledge Fundação de Amparo à Pesquisa do Estado de São Paulo (FAPESP) for financial assistance.

\section{References}

BONAGURA, J. D.; REEF, V. B.; SCHWARZWALD, C. C. Cardiovascular diseases. In: REED, S. M.; BAYLY, W. M.; SELLON, D. C. Equine internal medicine. St. Louis: Saunders, 2010. p. 372-487.

BÖNING, D.; MAASSEN, N. Point: lactic acid is the only physicochemical contributor to the acidosis of exercise. Journal of Applied Physiology, Bethesda, v. 105, n. 1, p. 358-359, 2008.

CARLSON, G. P. Interrelationships between fluid, electolyte and acid-base balance during maximal exercise. Equine Veterinary Journal, Hoboken, v. 27, p. 261-265, 1995. Supplement.

DIAS, D. P. M.; CANOLA, P. A.; TEIXEIRA, L. G.; BERNARDI, N. S.; GRAVENA, K.; SAMPAIO, R. C. L.; ALBERNAZ, R. M.; SOARES, L. M. C.; BECHARA, G. H.; CANOLA, J. C.; LACERDA-NETO, J. C. A reproducible venous thrombosis model in horses induced by the combination of an endothelial lesion and blood flow stasis. Journal of Equine Veterinary Science, New York, v. 34, n. 4, p. 578-587, 2014.

DIAS, D. P. M.; SILVA, M. A. G.; ALBERNAZ, R. M.; GOMIDE, L. M. W.; MARTINS, C. B.; BERNARDI, N. S.; BARBOSA, J. C.; QUEIROZ-NETO, A.; LACERDANETO, J. C. Effects of jugular vein occlusion on cardiovascular parameters in horses during exercise on a treadmill. Journal of Equine Veterinary Science, New York, v. 33, n. 10, p. 763-772, 2013.

DIAS, D. P. M.; TEIXEIRA, L. G.; CANOLA, P. A.; ALBERNAZ, R. M.; MARQUES, J. A.; LACERDANETO, J. C. Long-term facial artery catheter implantation for serial arterial blood sampling and invasive arterial blood pressure measurement in horses. The Veterinary Journal, London, v. 192, n. 3, p. 541-543, 2012.

EDENS, L. M. Iatrogenic thrombophlebitis. In: COLAHAN, P. T.; MATHEW, I. G.; MERRITT, A. M.; MOORE, J. N. Equine medicine and surgery. St. Louis: Mosby, 1999. p. 416-419.

HINCHCLIFF, K. W.; GEOR, R. J. Integrative physiology of exercise. In: HINCHCLIFF, K. W.; KANEPS, A. J.; GEOR, R. J. Equine sports medicine and surgery. Philadelphia: Saunders, 2004. p. 3-8.
HUSSNI, C. A.; BARBOSA, R. G.; BORGHESAN, A. C.; ROLLO, H. A.; ALVES, A. L. G.; WATANABE, M. J.; MACHADO, V. M. V.; CERQUEIRA, N. F. Equine experimental thrombophlebitis: Clinical, ultrasonographic and venographic evaluation. Pesquisa Veterinária Brasileira, Seropédica, v. 32, n. 7, p. 595600, 2012.

LANKVELD, D. P. K.; ENSINK, J. M.; VAN DIJK, P.; KLEIN, W. R. Factors influencing the occurrence of thrombophlebitis after post-surgical long-term intravenous catheterization of colic horses: a study of 38 cases. Journal of Veterinary Medicine Series A, Berlim, v. 48, n. 9, p. 545-552, 2001.

LINDINGER, M. I. Acid-base physiology during exercise and in response to training. In: HINCHCLIFF, K. W.; KANEPS, A. J.; GEOR, R. J. Equine sports medicine and surgery. Philadelphia: Saunders, 2004. p. 872-897.

LINDINGER, M. I.; HEIGENHAUSER, G. J. F. Counterpoint: lactic acid is not the only physicochemical contributor to the acidosis of exercise. Journal of Applied Physiology, Bethesda, v. 105, n. 1, p. 359-361, 2008.

MARTIN, B. B.; REEF, V. B.; PARENTE, E. J.; SAGE, A. D. Causes of poor performance of horses during training, racing, or showing: 348 cases (1992-1996). Journal of the American Veterinary Medical Association, Schaumburg, v. 216, n. 4, p. 554-558, 2000.

MOREAU, P.; LAVOIE, J. P. Evaluation of athletic performance in horses with jugular vein thrombophlebitis: 91 cases (1988-2005). Journal of the American Veterinary Medical Association, Schaumburg, v. 235, n. 9, p. 10731078, 2009.

RUSSELL, T. M.; KEARNEY, C.; POLLOCK, P. J. Surgical treatment of septic jugular thrombophlebitis in nine horses. Veterinary Surgery, Malden, v. 39, n. 5, p. 627-630, 2010.

TAN, R. H. H.; DOWLING, B. A.; DART, A. J. Highspeed treadmill videoendoscopic examination of the upper respiratory tract in the horse: the results of 291 clinical cases. The Veterinary Journal, London, v. 170, n. 2, p. 243-248, 2005.

VAN ERCK-WESTERGREN, E.; FRANKLIN, S. H.; BAYLY, W. M. Respiratory diseases and their effects on respiratory function and exercise capacity. Equine Veterinary Journal, Hoboken, v. 45, n. 3, p. 376-387, 2013. 